\title{
PEMILIHAN LOKASI PERUMAHAN BAGIAN BARAT URBAN FRINGE KOTA SURAKARTA
}

\author{
Nabila Anindita1, Winny Astuti', Ana Hardiana1 \\ ${ }_{1}$ Program Studi Perencanaan Wilayah dan Kota, Fakultas Teknik, Universitas Sebelas Maret
}

\begin{abstract}
Abstrak
Perkembangan Kota Surakarta menjadikanya memiliki daya tarik yang kuat bagi pendatang. Hal tersebut menjadi pendorong berkembangnya daerah di sekitarnya. Perkembangan yang pesat, ramai, dan padat meminimalkan ketersediaan lahan serta menjadikan Kota Surakarta tidak lagi sesuai untuk menjadi lokasi tempat tinggal. Urban fringe merupakan daerah perbatasan antara kota dan desa yang memiliki sifat mirip dengan perkotaan. Sejalan dengan perkembangan Kota Surakarta yang mempunyai berbagai aktivitas yang kompleks, urban fringe berfungsi sebagai penyangga yang secara langsung mendapat dampak terhadap perkembangan Kota Surakarta. Kebutuhan tempat tinggal merupakan permasalahan yang berkaitan dengan aktivitas kependudukan. Semakin banyaknya penduduk, semakin banyak pula kebutuhan akan rumah. Minimnya ketersediaan lahan di Kota Surakarta untuk memenuhi kebutuhan tempat tinggal, dan kondisi bagian barat urban fringe Kota Surakarta yang ternyata mempunyai kriteria sebagai lokasi yang sesuai sebagai daerah perumahan dan permukiman, mendorong munculnya perumahan-perumahan baru. Sebagai dampaknya perumahan baru yang dibangun di bagian barat urban fringe Kota Surakarta antara lain Perumahan Permata Buana, Perumahan Puri Angkasa, Perumahan The Aleya, dan lainnya. Penelitian ini dilakukan untuk mengetahui faktor prioritas yang mempengaruhi pemilihan lokasi perumahan bagian barat urban fringe Kota Surakarta menggunakan analisis AHP. Berdasarkan hasil analisis, ditemukan bahwa faktor prioritas secara berurutan yaitu kenyamanan lingkungan perumahan, kemudahan dalam aksesibilitas, ketersediaan sarana \& prasarana penunjang perumahan, kondisi lingkungan fisik \& sosial, kebijakan \& hukum pendirian perumahan, dan harga kawasan perumahan.
\end{abstract}

Kata kunci: AHP; pemilihan lokasi perumahan; perumahan urban fringe

\begin{abstract}
The development of Surakarta City makes it a strong attraction for migrants. This growth stimulates the development of the surrounding area. Rapid, crowded and congested developments minimize the availability of land and make Surakarta City no longer suitable for its residents to live. Urban fringe is a border area between cities and villages that has similar characteristics to cities. In line with the development of Surakarta City which has a variety of complex activities, urban fringe serves as a buffer that is directly affected by the development of Surakarta City. Housing needs are problems that related to population activities. The bigger number of population, the higher demand for housing will emerge.. Currently, of the available land in Surakarta City to meet residential needs is lacking, while the western part of the urban fringe of Surakarta City turns out to have an appropriate criteria as for residentiallocation. As a result, new housing developments emerged in the western part of the urban fringe in Surakarta City such as Housing Permata Buana, Puri Angkasa Housing, The Aleya Housing, and others. This study was conducted to determine the priority factors that influence the selection of residential locations in the western part of the urban fringe of Surakarta City using AHP analysis. Based on the results of the analysis, it was found that the priority factors in sequence were the comfort of the housing environment, ease of accessibility, availability of facilities \& infrastructure to support housing, physical \& social environmental conditions, policy \& legal housing establishment, and housing area prices.
\end{abstract}

Keywords: AHP; housing location selection; urban fringe housing

\section{PENDAHULUAN}

Perkembangan Kota Surakarta dari segi penduduk dan fasilitas menjadikan Kota Surakarta memiliki daya tarik yang kuat bagi pendatang dari berbagai daerah. Hal tersebut menjadi pendorong berkembangnya daerah di sekitarnya. Perkembangan 
Kota Surakarta yang pesat, ramai, dan padat dalam segala hal seperti padat penduduk, bangunan, dan transportasi semakin meminimalkan ketersediaan lahan serta menjadikan Kota Surakarta tidak lagi sesuai untuk menjadi lokasi bertempat tinggal.

Urban fringe merupakan daerah perbatasan antara kota dan desa yang memiliki sifat yang mirip dengan daerah wilayah perkotaan. Urban fringe merupakan daerah pinggiran kota yang berada dalam proses transisi dari daerah perdesaan menjadi daerah perkotaan. Sejalan dengan perkembangan Kota Surakarta yang mempunyai berbagai aktivitas yang kompleks, kawasan pinggiran (urban fringe) berfungsi sebagai penyangga yang secara langsung mendapat dampak terhadap perkembangan Kota Surakarta. Fakta lapangan dan data pada dokumen Kecamatan Colomadu Dalam Angka, bagian barat urban fringe Kota Surakarta mengalami perubahan guna lahan secara perlahan dari daerah non terbangun menjadi terbangun.

Kebutuhan tempat tinggal merupakan permasalahan yang berkaitan dengan aktivitas kependudukan. Semakin banyaknya penduduk, semakin banyak pula kebutuhan akan rumah. Akibat minimnya ketersediaan lahan di Kota Surakarta untuk memenuhi kebutuhan tempat tinggal, fenomena bagian barat urban fringe Kota Surakarta mempunyai kriteria sebagai lokasi yang sesuai sebagai daerah perumahan dan permukiman. Ditambah lagi kebijakan pemerintah yang melakukan peninjauan bagian barat urban fringe Kota Surakarta terkait kesesuaian lokasinya sebagai permukiman baru bagi penduduk limpahan Kota Surakarta sehingga dilakukan kerjasama antar stakeholder yang berkaitan dengan pembangunan perumahan.

Pemilihan lokasi perumahan adalah hal yang penting, karena dengan lokasi yang sesuai, aktivitas perumahan akan berjalan dengan baik. Menurut Catanese \& Snyder (1989), terdapat beberapa kriteria dalam memilih lokasi perumahan yaitu kemudahan dalam aksesibilitas, kondisi lingkungan fisik \& sosial, ketersediaan sarana \& prasarana penunjang perumahan, harga kawasan perumahan, dan kebijakan \& hukum pendirian perumahan. Lebih detail menurut Szelenyi dan Pichler Milanovich dalam Kahrik \& Tammaru (2008), (Turner, 1976), (Budiharjo, 1998) menyatakan bahwa di urban fringe mempunyai karakteristik perumahan yang berbeda yaitu tersedianya kenyamanan lingkungan perumahan. Kriteria-kriteria tersebut dapat ditemukan di bagian barat urban fringe Kota Surakarta, sehingga terjadi pembangunan perumahan baru di bagian barat urban fringe Kota Surakarta seperti Perumahan Permata Buana, Perumahan Puri Angkasa, Perumahan The Aleya, dan masih banyak lagi. Hal ini menimbulkan pertanyaan penelitian yaitu faktor-faktor apa yang mempengaruhi pemilihan lokasi perumahan menurut stakeholder (pemerintah dan developer) di bagian barat urban fringe Kota Surakarta.

\section{KAJIAN PUSTAKA}

\subsection{PENGERTIAN DAN KOMPONEN PERUMAHAN}

Pengertian perumahan berdasarkan UU Nomor 1 Tahun 2011 tentang Perumahan dan Kawasan Permukiman menjelaskan bahwa perumahan adalah kumpulan rumah sebagai bagian dari permukiman, baik perkotaan maupun perdesaan yang dilengkapi dengan sarana, prasarana, dan utilitas umum sebagai hasil upaya pemenuhan rumah yang layak huni. Perumahan tidak hanya sebuah bangunan fisik yang memberi nauangan yang bertempat tinggal, namun juga dipergunakan untuk melayani berbagai kebutuhan di dalam maupun di lingkunganya dan menciptakan suatu lingkungan perumahan yang layak serta dapat mengakomodiasi berbagai kebutuhan adalah hal yang penting.

Komponen perumahan merupakan suatu sistem yang terdiri dari unsur alam mencakup sumber daya, topografi, hidrologi, tanah, iklim, unsur hayati, manusia yang melangsungkan kegiatan, tempat dimana manusia melangsungkan kegiatanya, dan jaringan yang merupakan sistem alami dan buatan manusia yang menunjang fungsi lingkungan perumahan seperti jaringan jalan, air bersih, dan sebagainya (Bayuprima et.al, 2016). Unsur-unsur dalam komponen perumahan lainnya dijabarkan oleh Blaang (1986) yaitu secara ringkas seperti lingkungan yang alami, keberadaan kegiatan sosial manusia, bangunan rumah tinggal, ketersediaan sarana dan prasarana. Selain itu, penjelasan mengenai komponen dan parameter perumahan yang baik dari Sinulingga (1999) dalam (Lollyanti, Normelani, \& Adyatma, 2017) mempunyai empat komponen inti yaitu nilai lahan/tanah yang berpengaruh pada harga, prasarana penunjang, kondisi perumahan yang dibangun, dan fasilitas umum hingga khusus di area perumahan. 


\subsection{FAKTOR PEMILIHAN LOKASI PERUMAHAN}

\subsubsection{Kemudahan dalam Aksesibilitas}

Aksesibilitas adalah derajat kemudahan yang dicapai oleh seseorang terhadap suatu obyek, pelayanan, dan lingkungan. Aksesibilitas merupakan ukuran kemudahan lokasi untuk dijangkau dari lokasi lainya melalui sistem transportasi. Ukuran keterjangkauan aksesibilitas meliputi kemudahan dalam waktu, biaya, dan usaha dalam melakukan perpindahan. Aksesibilitas merupakan jangkauan jarak yang dapat meminimalkan perjalanan ke berbagai fasilitas dan adanya penyediaan transportasi umum (Drabkin, 1980). Daya tarik suatu lokasi perumahan ditentukan oleh aksesibilitas. Aksesibilitas merupakan daya tarik suatu lokasi perumahan dikarenakan dapat memperoleh kemudahan dalam pencapaian dari berbagai pusat kegiatan (Luhst, 1997). Selanjutnya teori dari Catanese \& Snyder (1989) mengatakan bahwa dalam memilih lokasi perumahan mempertimbangkan lokasi yang strategis, aksesibilitas baik, dilewati transportasi umum dan mudah untuk dilewati pejalan kaki. Bourne (1975) dan Rencana Kawasan Perumahan Kota yang disusun oleh Dinas Pekerjaam Umum (1997) juga mengedepankan faktor aksesibilitas yang meliputi keterjangkauan dengan berbagai fasilitas. Kemudahan transportasi dilihat seperti halnya kedekatan menuju ke pusat kota dan ketersediaan angkutan umum lokal sehingga memudahkan mencapai suatu lokasi penting. Terdapat hubungan erat antara ketersediaan angkutan umum dengan pertumbuhan perumahan. Adanya pelayanan angkutan umum maka memudahkan dalam mencapai lokasi perumahan sehingga semakin baik pelayanan transportasinya mempengaruhi suatu pertumbuhan perumahan dan permukiman (Koestoer, 2001) dalam (Asteriani, 2010).

\subsubsection{Kondisi Lingkungan Fisik dan Sosial}

Aca Sugandi (2005) dalam (Asteriani, 2010) mengatakan bahwa kebijakan Pemerintah dalam penyelenggaraan perumahan diarahkan agar mampu memenuhi kebutuhan rumah yang layak dan terjangkau pada lingkungan yang sehat, keamanan, harmonis, dan berkelanjutan sehingga pemenuhan ini sebagai pemenuhan kebutuhan lingkungan yang sehat dan konsepsional. Menurut Rencana Kawasan Perumahan Kota yang disusun oleh Dinas Pekerjaam Umum (1997) mengatakan juga tentang fleksibilitas yaitu pertumbuhan fisik kawasan perumahan dengan kondisi lingkungan fisiknya. Luhst (1997) dalam (Asteriani, 2010) menyebutkan bahwa salah satu daya tarik suatu lokasi perumahan ditentukan oleh lingkungan. Lingkungan yaitu sebagai suatu wilayah yang secara geografis dibatasi dengan batas nyata, mengandung unsur fisik dan sosial yang menimbulkan suatu kegiatan.

Karakteristik fisik dan lingkungan alam hingga keadaan lingkungan sosial, demografi, dan sosial ekonomi masyarakat menjadi salah satu faktor dalam memilih lokasi perumahan (Bourne, 1975) dalam (Kalesaran, Mandagi, \& Waney, 2013). Kawasan yang digunakan untuk lokasi perumahan mempunyai keadaan tanah dan topografi yang baik dan cocok untuk didirikan suatu bangunan. Kawasan yang digunakan untuk perumahan mempertimbangkan juga dampak pembangunan terhadap masyarakat di sekitarnya (Catanese \& Snyder, 1989). Kemudian dari Drabkin (1980) dalam (Kalesaran, Mandagi, \& Waney, 2013) mengemukakan bahwa faktor yang mempengaruhi dalam pemilihan lokasi perumahan adalah memperhatikan aspek lingkungan fisik yang berupa keadaan alam, geografis, topografinya, kondisi tanah, lingkungan sosial berupa kondisi masyarakat di sekitarnya yang menghuni kawasan tersebut, kebisingan, polusi, dan kenyamanan lingkungan. Ada beberapa hal juga yang perlu diperhatikan dalam memilih lokasi perumahan yaitu bukan daerah rawan bencana, tanahnya baik sehingga konstruksi bangunan dapat berdiri, tidak merusak lingkungan, mempertahankan tanah yang berfungsi sebagai reservoir air tanah (Budiharjo, 1998).

\subsubsection{Ketersediaan Sarana dan Prasarana Penunjang Perumahan}

Kawasan yang digunakan untuk lokasi perumahan mempunyai fasilitas prasarana yang lengkap seperti jaringan listrik, telepon, drainase, air bersih, sanitasi, dan alarm bahaya (Catanese \& Snyder, 1989). Rencana Kawasan Perumahan Kota yang disusun oleh Dinas Pekerjaan Umum (1997) mengatakan bahwa lokasi perumahan harus menyediakan sarana dan prasarana penunjang perumahan untuk mendukung aktifitas di dalamnya. Drabkin (1980) dalam (Kalesaran, Mandagi, \& Waney, 2013) juga mengemukakan lokasi perumahan mempunyai tingkat pelayanan dalam hal sarana prasarana yang baik seperti tersedia dan berfungsinya prasarana penunjang perumahan (jaringan listrik, drainase, air bersih, sanitasi, telepon) dan terlayani oleh sarana umum. Ada beberapa hal juga yang perlu diperhatikan dalam memilih lokasi perumahan menurut 
Budiharjo (1998) yaitu mudah mendapatkan sumber air bersih, listrik, pembuangan air limbah, sekolah, pasar, puskesmas, dan kebutuhan manusia di dalamnya.

\subsubsection{Harga Lahan/Kawasan Perumahan}

Pengukuran nilai lahan didasarkan pada kemampuan lahan secara ekonomis dalam hubungannya dengan produktivitas dan strategi ekonomis. Sedangkan harga lahan/kawasan adalah penilaian atas lahan yang diukur berdasarkan harga nominal dalam satuan uang untuk satu satuan luas tertentu (Yunus, 2000:89). Catanese \& Snyder (1989) mengatakan tentang kawasan yang digunakan untuk lokasi perumahan mempunyai harga lahan yang relatif terjangkau. Selain terjangkau, lahan tersebut juga mempunyai berbagai keuntungan yang dapat dihasilkan di lokasi perumahan tersebut. Sama halnya dengan kriteria dalam pemilihan perumahan rumah menurut Hapsarinity (2013) dalam (Putra \& Rahayu, 2015).

\subsubsection{Kebijakan dan Hukum Pendirian Perumahan}

Catanese \& Snyder (1989) mengatakan bahwa kawasan yang digunakan untuk lokasi perumahan mempunyai izin dalam mendirikan bangunan, lokasi tidak termasuk dalam kawasan lindung, lokasinya memenuhi persyaratan lingkungan, dan tidak berada di kawasan yang rawan bencana. Diperkuat lagi dengan SNI 03-1733-2004 tentang tata cara perencanaan lingkungan perumahan, lokasi perumahan harus sesuai dengan Rencana Tata Ruang Wilayah (RTRW) setempat atau dokumen perencanaan tata ruang lainya yang ditetapkan dengan Peraturan Daerah setempat dan memenuhi persyaratan lokasi perumahan tidak berada pada kawasan lindung.

\subsection{Pengertian dan Karakteristik Urban Fringe}

Konsep urban fringe digunakan untuk mengidentifikasi suatu wilayah yang ditandai oleh adanya percampuran yang sangat intens mengenai kegiatan pertanian dan non pertanian (McGee, 1991, dalam Giyarsih, 2009). Daerah urban fringe merupakan daerah peralihan atau transisi antara kenampakan perkotaan dan perdesaan. Hal ini menjadikan kawasan urban fringe memiliki ciri perkotaan maupun perdesaan terutama pada penggunaan lahan. Dirjen Penataan Ruang menjelaskan kawasan urban fringe memiliki karakteristik yang berbeda jika dibandingkan dengan perkotaan. Wilayah urban fringe memiliki kriteria kawasan dengan adanya permukiman berskala kecil dan besar dengan kepadatan campuran, mempunyai harga lahan yang relatif rendah, belum maksimalnya aksesibilitas jaringan jalan yang memudahkan menuju pusat kota.

Ada empat karakter yang dapat digunakan untuk membedakan daerah urban fringe yaitu daerah ini sebelumnya merupakan daerah perdesaan dengan dominasi guna lahan sebagai pertanian mempunyai kondisi sosial komunitas masyarakat masih menunjung tinggi kebudayaan desa. Setelah adanya serbuan penduduk kota menuju urban fringe, daerah urban fringe menjadi daerah yang diinvasi oleh penduduk dari perkotaan sehingga kondisi sosialnya perlahan berubah menjadi kekotaan. Semakin kekotaannya daerah ini, muncul beragam konflik berbagai pihak di dalamnya, salah satunya adalah banyak terjadi ajang spekulasi tanah bagi developer (Russwurnm, 1986, dalam Giyarsih, 2009).

\subsection{Karakteristik Perumahan di Urban Fringe}

Urban fringe merupakan daerah perbatasan antara kota dan desa yang memiliki sifat mirip dengan wilayah perkotaan (Yunus, 2008). Wilayah urban fringe yang awalnya bersifat pedesaan mengalami transisi menjadi perkotaan dikarenakan aktifitas kependudukan. Akibat minimnya ketersediaan lahan di kota untuk memenuhi kebutuhan tempat tinggal, maka urban fringe menjadi pilihan yang tepat dalam pengadaan kebutuhan tempat tinggal. Perumahan \& permukiman di wilayah urban fringe mempunyai karakter yang berbeda dengan di perkotaan. Berikut merupakan pemahaman dari beberapa pakar terkait karakteristik perumahan \& permukiman di wilayah urban fringe.

\subsubsection{Kenyamanan Lingkungan Perumahan}

Menurut Szelenyi dalam (Kahrik \& Tammaru, 2008) menyebutkan bahwa bermigrasi untuk bertempat tinggal ke urban fringe karena faktor kenyamanan dan keadaan lingkungan yang baik. Segi kenyamanan di wilayah urban fringe adalah lingkungan perumahan yang jauh dari kebisingan, polusi udara, dan hiruk pikuk perkotaan diungkapkan oleh PichlerMilanovich dalam (Kahrik \& Tammaru, 2008). Faktor kenyamanan memang menjadi titik berat di wilayah urban fringe 
dikarenakan hal itulah yang membedakan perumahan di urban fringe dengan yang berada di perkotaan. Urban fringe masih memiliki kawasan yang guna lahan nya pertanian sehingga dari sana dapat diciptakan ruang kenyamanan bagi perumahan yang berlokasi di urban fringe (Turner, 1976). Ada beberapa hal juga yang diperhatikan dalam memilih lokasi perumahan di urban fringe yaitu adalah jauh dari aktifitas yang dapat mengganggu kenyamanan perumahan seperti aktifitas pabrik yang dapat mendatangkan berbagai macam masalah seperti debu pabrik, buangan sampah, limbah pabrik, dan kebisingan (Budiharjo, 1998).

\subsubsection{Kemudahan Dalam Aksesibilitas}

Aksesibilitas adalah derajat kemudahan yang dicapai oleh seseorang terhadap suatu obyek, pelayanan, dan lingkungan. Aksesibilitas merupakan ukuran kemudahan lokasi untuk dijangkau dari lokasi lainnya melalui sistem transportasi. Ukuran keterjangkauan aksesibilitas meliputi kemudahan dalam waktu, biaya, dan usaha dalam melakukan perpindahan. Teori dari Pichler-Milanovich dalam (Kahrik \& Tammaru, 2008) menyebutkan bahwa memilih perumahan di urban fringe karena adanya penyebaran jalur transportasi yang dapat memudahkan pergerakan manusia. Penduduk yang berada di wilayah urban fringe dapat juga menggunakan sarana transportasi berupa bus dan angkutan umum yang melintasi sepanjang jalan dari urban fringe hingga ke pusat kota. Aksesibilitas yang baik di wilayah urban fringe menjadi salah satu penarik untuk mendatangkan penduduk dan mempermudah penduduk dalam pergerakannya (Wardana, 2007).

\subsubsection{Harga Lahan/Kawasan Perumahan}

Pengukuran nilai lahan didasarkan pada kemampuan lahan secara ekonomis dalam hubungannya dengan produktivitas dan strategi ekonomis. Sedangkan harga lahan/kawasan adalah penilaian atas lahan yang diukur berdasarkan harga nominal dalam satuan uang untuk satu satuan luas tertentu (Yunus, 2000). Nilai lahan sangat berkaitan dengan harga lahan/ kawasan dikarenakan harga lahan ada karena nilai lahannya ada. Harga lahan/kawasan di urban fringe dinilai lebih murah dengan nilai lahan yang baik dibandingkan dengan daerah perkotaan. Dengan keadaan seperti ini, para developer berlomba untuk membeli lahan di urban fringe dengan tujuan meraih keuntungan untuk dijadikan property yang menguntungkan.

Dirjen Penataan Ruang mengatakan bahwa daerah urban fringe memiliki harga lahan yang relatif rendah daripada perkotaan. Apalagi ditambah dengan hal yang penting dalam memilih lokasi perumahan urban fringe adalah mempunyai lokasi dengan biaya lahan yang relatif terjangkau dengan kemampuan lahan yang baik (Turner, 1976). Maka dalam praktiknya, developer menganggap tanah sebagai suatu komoditi untuk dibeli dengan harga rendah dan dijual dengan harga tinggi.

Dalam menentukan faktor pemilihan lokasi perumahan di urban fringe digunakan sintesa teori yang diambil dari beberapa ahli/pakar mengenai teori terkait. Hasil sintesa teori tersebut akan menjadi variabel dalam penelitian. Berikut merupakan variabel yang diambil dalam penelitian yaitu adalah kemudahan dalam aksesibilitas, kondisi lingkungan fisik \& sosial, ketersediaan sarana \& prasarana penunjang perumahan, harga kawasan perumahan, kebijakan \& hukum pendirian perumahan, dan kenyamanan lingkungan perumahan.

\section{METODE PENELITIAN}

\subsection{KAWASAN PENELITIAN}

Kawasan dalam penelitian ini yaitu wilayah bagian barat urban fringe Kota Surakarta yang terletak di Kecamatan Colomadu, Kabupaten Karanganyar (Gambar 1). Letaknya secara geografis terpisah dari kecamatan-kecamatan lainnya yang ada di Kabupaten Karanganyar. Kawasan penelitian mempunyai batas-batas kawasan yaitu sebelah barat dan utaranya adalah Kabupaten Boyolali, sebelah timurnya adalah Kota Surakarta, dan sebelah selatannya adalah Kabupaten Sukoharjo. Bagian barat urban fringe Kota Surakarta mempunyai keunikan yaitu seperti kondisi fisik yang mendukung pembangunan, tersedianya aksesibilitas jalan yang memudahkan hubungan antara lokasi penelitian dengan pusat Kota Surakarta dan adanya sarana \& prasarana yang menjadi pemicu pembangunan yang bergeser ke bagian barat urban fringe Kota Surakarta. 
Kawasan penelitian yang telah dilakukan delineasi hingga akhirnya ditetapkan adalah sebagian Kelurahan/Desa Bolon, sebagian Kelurahan/Desa Malangjiwan, Kelurahan/Desa Paulan, Kelurahan/Desa Gajahan, dan Kelurahan/Desa Blulukan yang berada di Kecamatan Colomadu, Kabupaten Karanganyar dengan total sebaran perumahan di kawasan penelitian sebanyak 38 perumahan. Gambar 1 adalah peta delineasi yang digunakan sebagai kawasan penelitian bagian barat urban fringe Kota Surakarta.

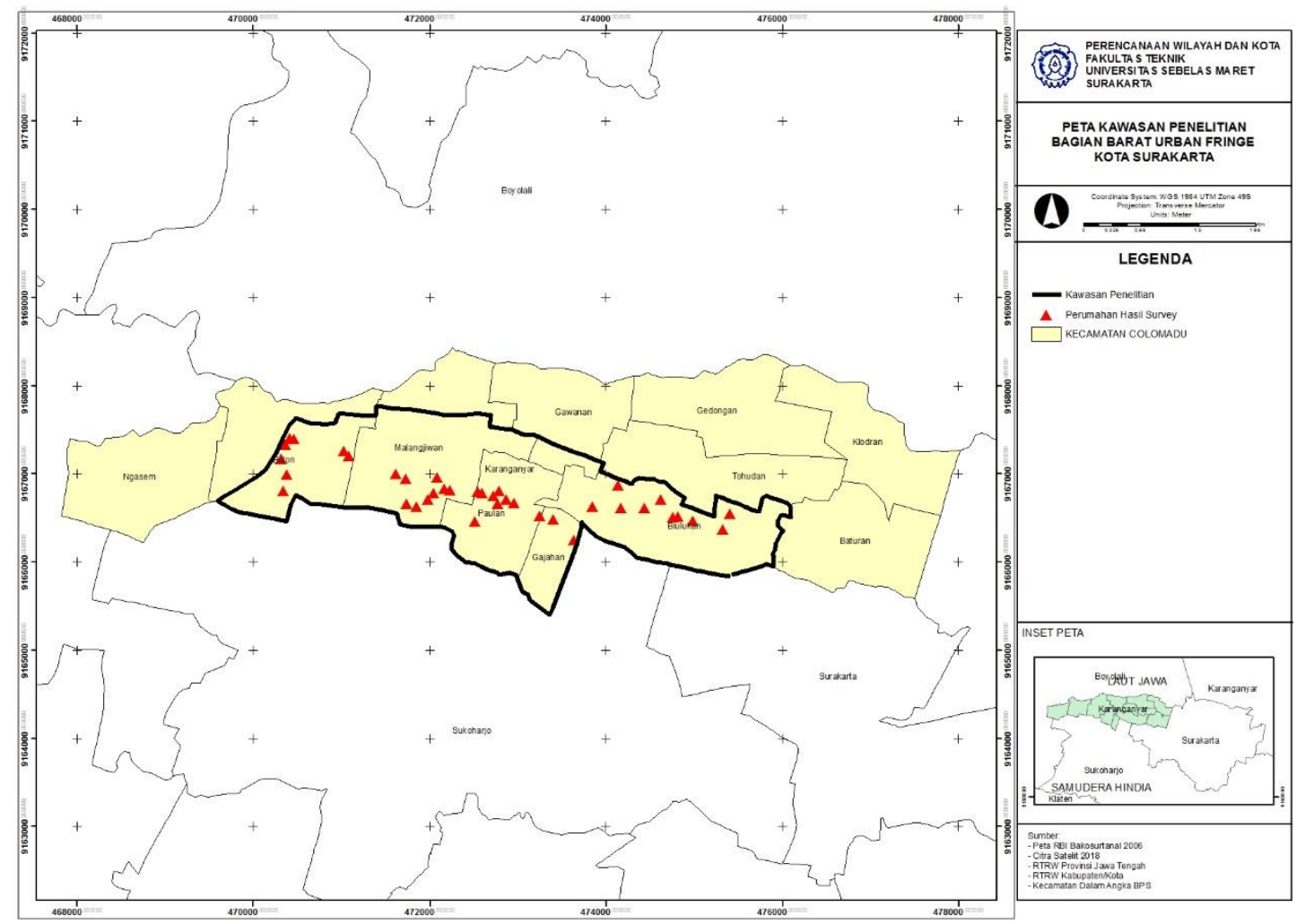

Gambar 1. Peta Kawasan Penelitian

\subsection{PENDEKATAN DAN JENIS PENELITIAN}

Penelitian yang mempunyai tujuan untuk mengetahui faktor dan prioritas faktor yang mempengaruhi pemilihan lokasi perumahan bagian barat urban fringe Kota Surakarta menggunakan cara deduktif, yaitu menempatkan masalah dalam kerangka berpikir teoritis. Jenis penelitian yang dilakukan adalah penelitian kuantitatif yang dari awal telah diketahui variabel dan data yang akan diukur. Penelitian ini menggunakan teknik Analytical Hierarchy Process (AHP) yang merupakan metode untuk memecahkan suatu situasi yang kompleks tidak terstuktur ke dalam beberapa komponen dalam susunan yang hierarki dengan memberi nilai tentang pentingnya setiap variabel.

\subsection{TEKNIK PENGUMPULAN DATA}

Teknik pengumpulan data yang dilakukan dalam penelitian ini adalah teknik pengumpulan data primer dan pengumpulan data sekunder. Teknik pengumpulan data primer yaitu observasi lapangan, wawancara, dan kuesioner yang dilakukan untuk mengetahui keadaan/kondisi perumahan formal yang menjadi obyek dalam penelitian ini dan kuesioner AHP yang ditujukan untuk narasumber yang mempunyai bidang keahlian dan kepentingan dalam penelitian. Dilanjutkan teknik pengumpulan data sekuder yaitu pengumpulan data yang dilakukan dari data tertulis seperti studi literatur, dokumen, aturan perundangan, dan lainnya yang disusun oleh pihak yang berkepentingan seperti Pemerintah atau penelitian sebelumnya. 
Tabel 1. Faktor Pemilihan Lokasi Perumahan Urban Fringe

\begin{tabular}{|c|c|c|c|}
\hline $\begin{array}{c}\text { Faktor Pemilihan Lokasi } \\
\text { Perumahan }\end{array}$ & $\begin{array}{c}\text { Karakteristik Lokasi } \\
\text { Perumahan Di Urban Fringe }\end{array}$ & Variabel Terpilih & Indikator \\
\hline $\begin{array}{l}\text { Kemudahan Dalam } \\
\text { Aksesibilitas } \\
\text { Kondisi Lingkungan Fisik dan } \\
\text { Sosial } \\
\text { Ketersediaan Sarana dan } \\
\text { Prasarana Penunjang } \\
\text { Perumahan } \\
\text { Harga Kawasan Perumahan } \\
\text { Kebijakan dan Hukum } \\
\text { Pendirian Perumahan }\end{array}$ & $\begin{array}{l}\text { Kenyamanan Lingkungan } \\
\text { Perumahan }\end{array}$ & $\begin{array}{l}\text { Kondisi Lingkungan Fisik } \\
\text { dan Sosial } \\
\text { Ketersediaan Sarana dan } \\
\text { Prasarana Penunjang } \\
\text { Perumahan } \\
\text { Harga Kawasan } \\
\text { Perumahan } \\
\text { Kebijakan dan Hukum } \\
\text { Pendirian Perumahan } \\
\text { Kenyamanan Lingkungan } \\
\text { Perumahan }\end{array}$ & $\begin{array}{l}\text { - Ketersediaan jaringan transportasi } \\
\text { - Ketersediaan moda transportasi } \\
\text { - Ketersediaan halte } \\
\text { - Kondisi kemiringan tanah } \\
\text { - Jenis tanah } \\
\text { - Batas fisik } \\
\text { - Kondisi sosial masyarakat } \\
\text { - Ketersediaan sarana penunjang } \\
\text { - Ketersediaan prasarana } \\
\text { penunjang } \\
\text { - Harga lahan/ kawasan perumahan } \\
\text { - Kebijaan RTRW Kabupaten } \\
\text { - Izin pendirian bangunan } \\
\text { - Tingkat kebisingan } \\
\text { - Tingkat polusi udara }\end{array}$ \\
\hline
\end{tabular}

\subsection{TEKNIK ANALISIS DATA}

Pada penelitian ini menggunakan teknik Analisis Analytical Hierarchy Process (AHP) untuk membantu pengambilan keputusan yang komprehensif untuk menangani masalah yang kompleks. AHP memiliki tiga prinsip dalam membantu memecahkan persoalan dan menentukan alternatif pilihan yaitu hierarki, penetapan prioritas, dan konsistensi logis (Saaty, 2008). Hasil dari analisis AHP digunakan untuk menentukan faktor prioritas apa saja yang paling menentukan pemilihan lokasi perumahan bagian barat urban fringe Kota Surakarta. Berdasarkan faktor yang ada, akan dibuat kuesioner yang dibagikan kepada stakeholder antara lain pemerintah/instansional (Dinas Pekerjaan Umum, Dinas Tata Ruang, Dinas Perumahan dan Permukiman, BAPPEDA, Dinas Perhubungan, Kepala Kecamatan, Kepala Kelurahan), developer perumahan, dan akademisi (tata ruang dan perumahan) dengan memberikan nilai untuk masing-masing faktornya.

\section{HASIL DAN PEMBAHASAN}

\subsection{PERUMAHAN BAGIAN BARAT URBAN FRINGE KOTA SURAKARTA}

Perkembangan lahan terbangun salah satunya didominasi oleh perumahan-perumahan baru di bagian barat urban fringe Kota Surakarta. Persebarannya dapat dilihat pada Gambar 1. Pembangunan perumahan-perumahan baru tersebut terus bermunculan dan selalu bertambah kuantitasnya.

Tabel 2. Daftar Perumahan di Lokasi Penelitian

\begin{tabular}{ccl}
\hline Kelurahan/Desa & Nomor Perumahan & \multicolumn{1}{c}{ Nama Perumahan } \\
\hline \multirow{3}{*}{ Malangjiwan } & 1 & Mahkota Klegen \\
& 2 & Aleya \\
& 3 & Grand Baituna \\
& 4 & Puri Malangjiwan Indah 2 \\
& 5 & Cempaka Asri 2 \\
& 6 & Puri Malangjiwan Indah 3 \\
& 7 & Tirtamaya Town House \\
\multirow{2}{*}{ Bolon } & 8 & Taman Pratama \\
& 9 & Puri Alam Asri 3 \\
& 10 & Kopassus Bolon \\
\hline
\end{tabular}


Desa-Kota, Vol. 3, No. 1, 2021, 61-76

\begin{tabular}{ccl}
\hline Kelurahan/Desa & Nomor Perumahan & \multicolumn{1}{c}{ Nama Perumahan } \\
\hline & 12 & Puri Bolon Indah \\
13 & Bolon Hijau \\
14 & Griya Padma Bolon \\
15 & Bolon Permai 1 \\
16 & Puri Angkasa Bolon \\
& 17 & Bolon Indah \\
& 18 & Taman Paulan Indah \\
& 19 & Prima Mandiri Residence \\
& 20 & Sangir Town House \\
& 21 & Rahman Hafiz \\
Paulan & 22 & Paulan Nirwana Regency \\
& 23 & Paulan Asri \\
& 24 & Mutiara Regency \\
& 25 & Taman Pandan \\
& 26 & Graha Sriti \\
& 27 & Permata Puri 2 \\
Blulukan & 28 & Habitat Estate \\
& 29 & Cempaka Asri 4 \\
& 30 & Blulukan Regency 2 \\
& 31 & Blulukan Indah \\
& 32 & Blulukan Regency 1 \\
& 33 & Flamboyan Indah 4 \\
& 34 & Gilang Residence \\
TOTAL: & Permata Buana \\
& 35 & Griya Pesona \\
& 36 & Puri Permata \\
& 37 & Grand Permata \\
& 38 & \\
& & \\
\hline
\end{tabular}

\subsection{IDENTIFIKASI FAKTOR PEMILIHAN LOKASI PERUMAHAN URBAN FRINGE}

\subsubsection{Faktor Kemudahan Dalam Aksesibilitas}

Kemudahan dalam aksesibilitas sangat menguntungkan untuk para konsumen perumahan di kawasan penelitian. Dilihat pada indikator ketersediaan jaringan transportasi, jalan di kawasan memiliki kondisi yang baik, beraspal, dan beberapa jalan perumahan menggunakan paving block. Untuk indikator ketersediaan moda transportasi pada kawasan penelitian memiliki pelayanan moda transportasi umum yaitu adanya jalur trayek BST koridor 4 dan koridor 8 , sedangkan untuk trayek angkutan umum ada pada jalur 02, 08, dan 09 yang semuanya telah didukung dengan adanya halte/pangkalan moda transportasi umum.

Hasil survey dan analisis oleh peneliti, keterjangkauan angkutan umum di kawasan penelitian untuk angkutan umum dapat menjangkau hampir semua perumahan yang ada di kawasan penelitian (Gambar 2). Namun, ada beberapa perumahan yang terlihat belum dapat terjangkau dari angkutan umum yaitu Perumahan Taman Paulan Indah, Perumahan Sangir Town House, Perumahan Prima Mandiri, dan Perumahan Griya Paulan Asri yang berada di Desa Paulan dan Perumahan Blulukan Regency 2 yang berada di Desa Blulukan. 


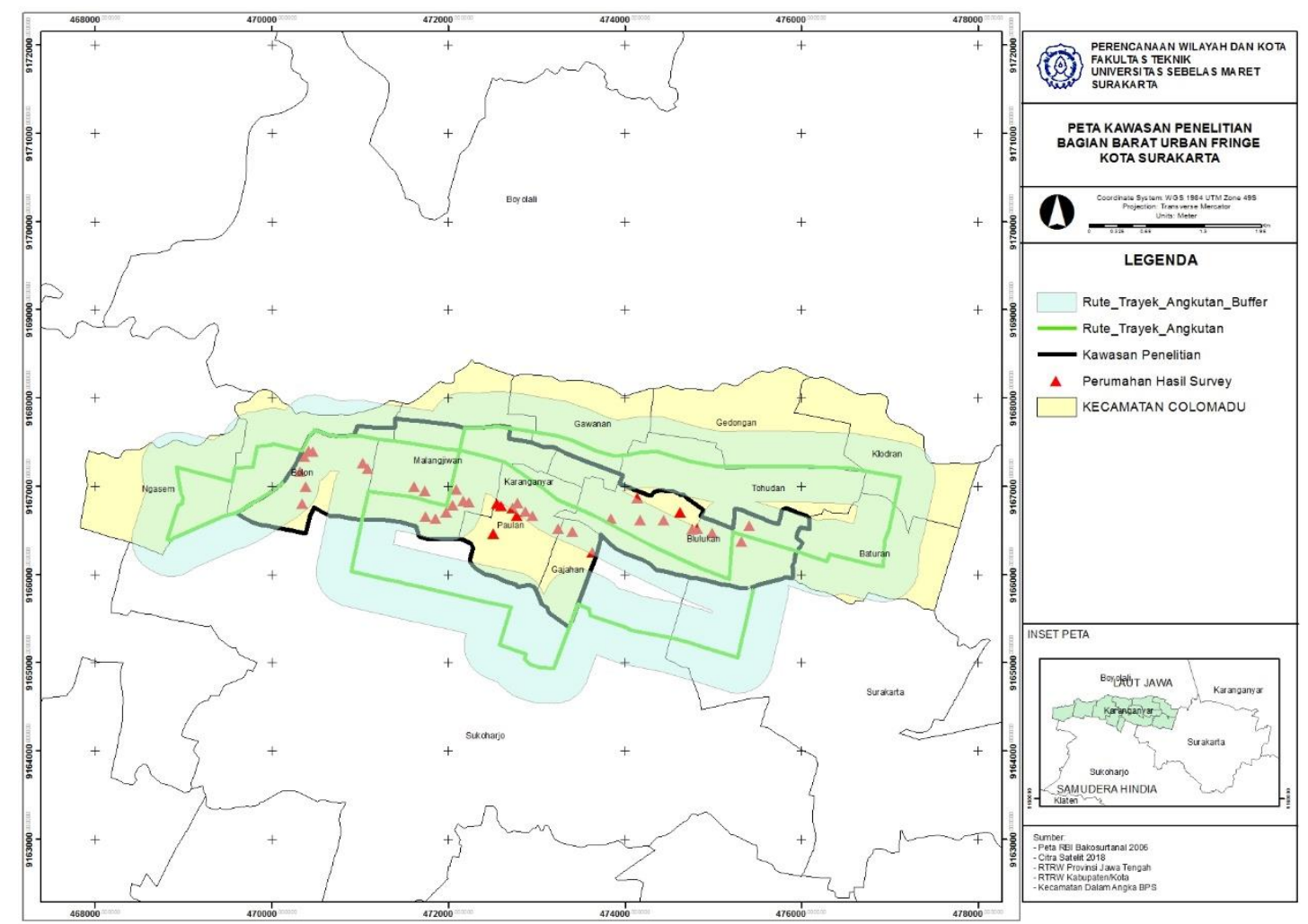

Gambar 2. Peta Jangkauan Pelayanan Angkutan Umum di Kawasan Penelitian

\subsubsection{Faktor Kondisi Lingkungan Fisik dan Sosial}

Lingkungan fisik di kawasan penelitian mempunyai rata-rata ketinggian sekitar 140 mdpl. Dikatakan daerah yang datar (tidak bergelombang) dengan kelerengan 0-8\% yang berarti cocok untuk dikembangkan sebagai kawasan budidaya. Jenis tanah yang ada di kawasan penelitian adalah tanah regosol kelabu dan mempunyai pH 6-7. Menurut RPJMD Kabupaten Karanganyar, kawasan penelitian tidak tergolong daerah yang rawan oleh bencana. Batas fisik merupakan batas-batas yang berdampingan langsung dengan perumahan di kawasan penelitian. Hasil pengamatan, ditemukan bahwa batas fisik perumahan di kawasan penelitian seperti persawahan, perumahan lainnya, sarana umum jangkauan kecil, dan lain sebagainya.

Masyarakat yang bermukim kebanyakan adalah sebagai komuter. Sebagai urban fringe Kota Surakarta, kawasan penelitian memiliki banyak warga yang menjadi komuter terutama ke Kota Surakarta. Kondisi masyarakat di area perumahan permukiman terlihat tidak terjadi konflik. Berdasarkan hasil wawancara yang telah dilakukan, ditemukan juga beberapa kegiatan kemasyarakatan yang dapat mengeratkan kesosialan masyarakat disana, antara lain PKK, Arisan RT, KSP per RW, Kerja Bakti, dan Karang Taruna baik per RT maupun RW. Hasil survey dan analisis oleh peneliti, kondisi lingkungan fisik dan sosial di kawasan penelitian dapat mendukung pembangunan perumahan baru yang baik dan ideal.

\subsubsection{Faktor Ketersediaan Sarana dan Prasarana Penunjang Perumahan}

Sarana dan prasarana merupakan hal yang sangat penting dalam menunjang kawasan perumahan. Dalam lingkungan perumahan, dibutuhkan sarana dan prasarana yang memadai dan nantinya akan menunjang aktifitas di dalamnya. Hal ini didukung oleh pemerintah yang mengeluarkan dan mengesahkan peraturan tentang pembangunan sarana dan prasarana penunjang perumahan. 


\subsubsection{Sarana Penunjang Perumahan}

Menurut KBBI, sarana adalah segala sesuatu yang dapat dapat dipakai sebagai alat dalam mencapai maksud dan tujuan. Sarana penunjang perumahan yaitu sarana pemerintahan, sarana pendidikan, kesehatan, peribadatan, perdagangan, dan RTH. Sarana-sarana ini nantinya dapat mendukung aktifitas kawasan perumahan. Tabel 3 merupakan sarana yang tersedia di kawasan penelitian.

Tabel 3. Sarana di Kawasan Penelitian

\begin{tabular}{|c|c|c|}
\hline No. & Sarana & Keterangan \\
\hline 1. & $\begin{array}{l}\text { Sarana Pemerintahan } \\
\text { dan Pelayanan Umum }\end{array}$ & $\begin{array}{l}\text { Kawasan penelitian sudah memiliki berbagai sarana pemerintahan dan pelayanan umum. } \\
\text { Sudah terlihat beberapa sarana yang berada di kawasan penelitian. Sarana pemerintahan } \\
\text { tersebut berupa kantor kecamatan dan kantor kelurahan. Sarana pelayanan umum tersebut } \\
\text { berupa Kantor Bea Cukai, Kantor Imigrasi, dan Polsek Colomadu. }\end{array}$ \\
\hline 2. & Sarana Pendidikan & $\begin{array}{l}\text { Kawasan penelitian sudah memiliki sarana pendidikan dari TK, SD, SMP, SMA, hingga } \\
\text { perguruan tinggi dan mereka saling terintegrasi. }\end{array}$ \\
\hline 3. & Sarana Kesehatan & $\begin{array}{l}\text { Kawasan penelitian sudah memiliki sarana kesehatan dari posyandu hingga rumah sakit, namun } \\
\text { ada beberapa desa yang belum mempunyai sarana kesehatan. Sarana kesehatan tersebut } \\
\text { berupa Poliklinik, Puskesmas, Pustu, dan Rumah Sakit. }\end{array}$ \\
\hline 4. & Sarana Peribadatan & $\begin{array}{l}\text { Kawasan penelitian sudah mempunyai sarana peribadatan yang tersebar di seluruh desa dan } \\
\text { terintegrasi bagi warga masyarakat. Sarana peribadatan tersebut berupa masjid dan gereja. }\end{array}$ \\
\hline 5. & Sarana Perekonomian & $\begin{array}{l}\text { Kawasan penelitian mempunyai persebaran sarana perekonomian di kawasan yang } \\
\text { kebanyakan berada di Jl. Adisucipto dan Jl. Adisumarmo. Sarana perekonomian tersebut } \\
\text { berupa minimarket dan toko-toko yang berbentuk ruko ritel. }\end{array}$ \\
\hline 6. & Sarana RTH & $\begin{array}{l}\text { Kawasan penelitian sudah mempunyai RTH yang memadai sehingga dapa dikatakan kawasan } \\
\text { ini merupakan kawasan yang nyaman dan sejuk. RTH tersebut berupa lapangan, lahan hijau, } \\
\text { dan persawahan. }\end{array}$ \\
\hline
\end{tabular}

Hasil survey dan analisis oleh peneliti, menunjukkan bahwa beberapa sarana telah dapat menjangkau semua perumahan yang ada di kawasan penelitian.

\subsubsection{Prasarana Penunjang Perumahan}

Prasarana adalah segala sesuatu yang merupakan penunjang utama terselenggaranya suatu proses. Prasarana penunjang perumahan seperti halnya jaringan listrik, telekomunikasi, sanitasi, air bersih, drainase, dan persampahan. Berikut merupakan ulasan singkat mengenai prasarana:

- Jaringan drainase: jaringan drainase di kawasan mempunyai 3 drainase yaitu drainase primer (berupa saluran alam yaitu S. Pepe, S. Tempuran, dan S. Maduh), drainase sekunder (drainase ini berada di sepanjang koridor jalan arteri dan kolektor yang mempunyai lebar sekitar 1-2 $\mathrm{m}$ dan kedalaman sekitar $0.8 \mathrm{~m}$ ), dan drainase tersier (drainase ini berada di sepanjang koridor jalan lokal dan lingkungan mempunyai lebar sekitar 0.5-0.9 m dan kedalaman sekitar 0.5 m).

- Jaringan air bersih: pemenuhan air bersih di kawasan penelitian memanfaatkan air tanah (sumur pompa) dan air permukaan (dikelola oleh PDAM dan didistribusikan ke seluruh wilayah kawasan penelitian). Selain itu juga pemenuhan air bersih melalui pembuatan sumur dangkal, namun ini hanya di beberapa lokasi saja.

- Jaringan air limbah/sanitasi: masyarakat menggunakan sumur resapan untuk membuang air cucian (limbah deterjen) ke sumur resapan yang dibuat secara pribadi maupun berkelompok sesuai dengan ketentuan yang berlaku.

- Jaringan persampahan: sistem jaringan persampahan di kawasan penelitian dikelola oleh Dinas Lingkungan Hidup Kabupaten Karanganyar dan masyarakat. Berdasarkan kondisi eksisting, terdapat 2 jenis pengelolaan sampah yaitu dibakar dan diambil oleh petugas lalu dibuang pada TPS di Kecamatan Colomadu dan pada akhirnya diangkut ke TPA Sukosari di Kecamatan Jumapolo, Kabupaten Karanganyar.

- Jaringan listrik: pemenuhan energi listrik di kawasan penelitian dipenuhi seluruhnya oleh PLN UPJ Kartasura. Jaringan listrik di kawasan penelitian berasal dari gardu induk jajar, untuk selanjutnya disalurkan ke gardu listrik dengan menggunakan saluran listrik tegangan tinggi (150KV) mengikuti jaringan jalan. Dari gardu distribusi, tegangan diturunkan sesuai kebutuhan dan disalurkan ke rumah-rumah.

- Jaringan telekomunikasi: jaringan telekomunikasi masyarakat di kawasan penelitian dipenuhi seluruhnya oleh PT. Telkom dan menggunakan tower BTS untuk mendapatkan sinyal telepon genggam. 
Hasil survey dan analisis oleh peneliti, menunjukkan bahwa prasarana telah dapat menjangkau semua perumahan yang ada di kawasan penelitian walaupun ditemukan beberapa masalah seperti aliran yang kurang lancar, terdapat tumpukan sampah di saluran, ada yang kering dan terdapat endapan pasir.

\subsubsection{Faktor Harga Lahan/Kawasan Perumahan}

Aktifitas pengembangan sejumlah proyek memicu kenaikan harga lahan/kawasan penelitian. Kenaikan harga lahan yang terjadi di kawasan bagian barat urban fringe dewasa ini disebabkan oleh segala kelengkapan fasilitas yang dibutuhkan telah tersedia dan booming-nya pembangunan property dan fasilitas jalan. Menurut hasil survey dari BPN Kabupaten Karanganyar, didapatkan data mengenai harga lahan kawasan perumahan antara tahun 2009-2018 (Tabel 4).

Tabel 4. Kisaran Harga Lahan di Kawasan Penelitian

\begin{tabular}{cl}
\hline Wilayah Perumahan & \multicolumn{1}{c}{ Harga rata-rata } \\
\hline Blulukan & Berkisar dimulai $641.000-3.768 .000 / \mathrm{m} 2$ \\
Bolon & Berkisar dimulai dari 1.023 .000 keatas $/ \mathrm{m} 2$ \\
Paulan & Berkisar dimulai dari 641.000 keatas $/ \mathrm{m} 2$ \\
Malangjiwan & Berkisar dimulai dari 2.390 .000 keatas $/ \mathrm{m} 2$ \\
Gajahan & Berkisar dimulai dari 1.526 .000 keatas $/ \mathrm{m} 2$ \\
\hline
\end{tabular}

Sumber : BPN Kabupaten Karanganyar, 2019

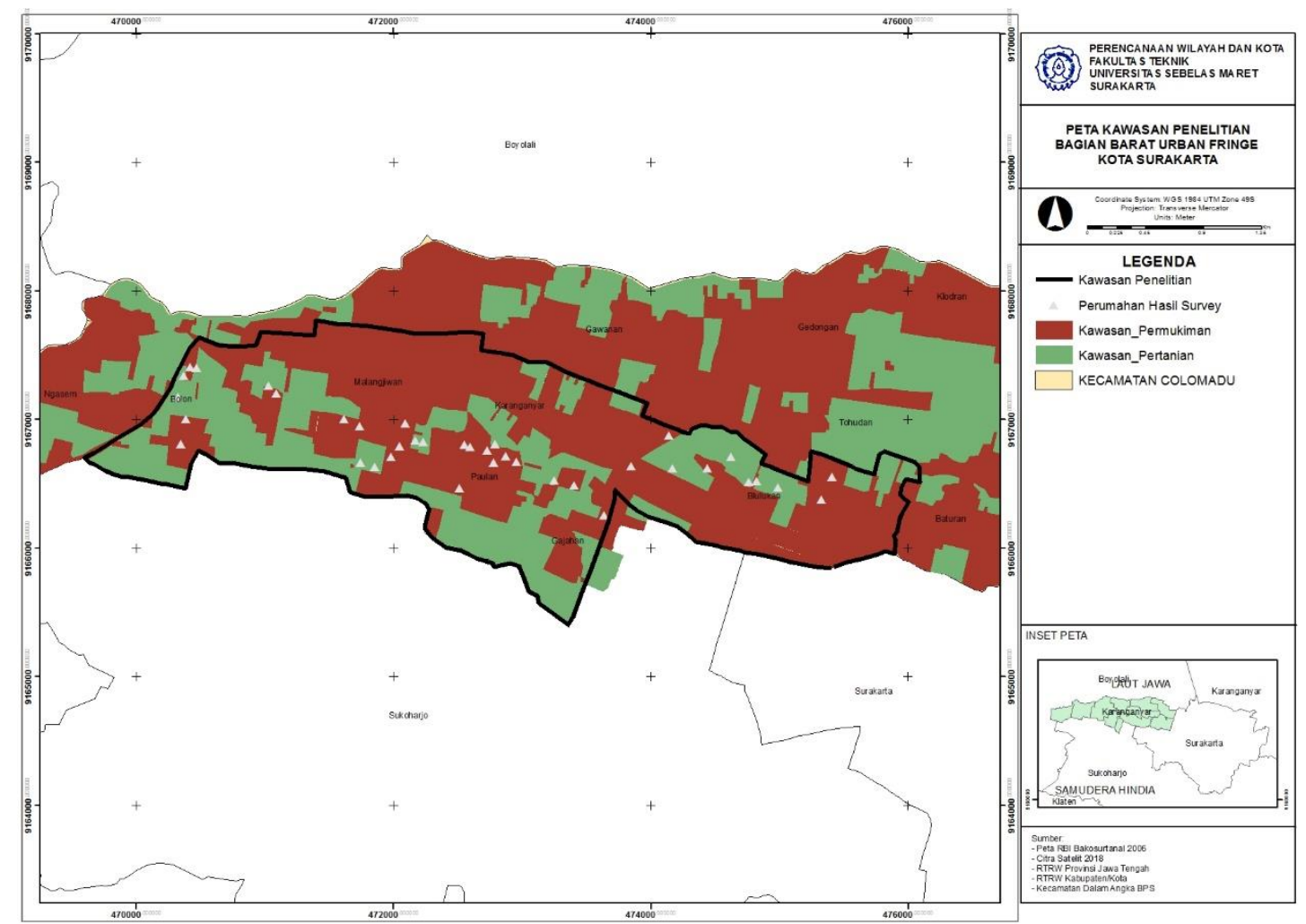

Gambar 3. Peta Kesesuaian Lokasi Perumahan dengan Peruntukan sesuai RTRW Kabupaten Karanganyar

\subsubsection{Faktor Kebijakan dan Hukum Pendirian Perumahan}

Menurut RTRW Kabupaten Karanganyar Tahun 2013-2032 dijelaskan bahwa kawasan penelitian mempunyai arahan pengembangan yang ditetapkan sebagai kawasan perumahan permukiman perkotaan. Setelah dilakukan survey dan analisis, ditemukan perumahan di kawasan penelitian sebagian besar sudah sesuai dengan lokasi peruntukkanya. Namun, ada beberapa perumahan yang berlokasi di kawasan yang bukan di peruntukkan untuk permukiman (Gambar 3) yaitu di 
Desa Bolon (Puri Bolon Indah dan Griya Padma Bolon), Desa Malangjiwan (Grand Baituna, Puri Malangjiwan Indah, Puri Malangjiwan 3, dan Tirtamaya Town House), Desa Gajahan (Grand Permata), dan di Desa Blulukan (Blulukan Indah, Blulukan Regency 2, Habitate Estate, dan Flamboyan Indah 4). Menurut ketentuan UU yang berlaku yaitu pasal 8 ayat (1) UU No 28 Tahun 2002 tentang bangunan harus memenuhi persyarakatan administratif yang meliputi status hak atas tanah, status kepemilikan bangunan, dan izin mendirikan bangunan. Setelah dilakukan survey oleh peneliti, didapatkan bahwa per bangunan perumahan-perumahan dikawasan penelitian, telah memiliki IMB yang dikantongi oleh masing-masing pemilik rumah.

\subsubsection{Faktor Kenyamanan Lingkungan Perumahan}

Fakta lapangan dan survey data dari Dinas Lingkungan Hidup Kabupaten Karanganyar di dapatkan tingkat kebisingan yaitu sebesar 56 dB dan substansi polusi udara di kawasan penelitian yaitu SO2, NO2, 03, H2S, NH3, TSP/debu, Pb, CO. Hal-hal di lapangan yang sekiranya dapat mengganggu kenyamanan lingkungan perumahan adalah polusi udara karena kendaraan bermotor, polusi udara yang disebabkan oleh pembakaran sampah hasil aktifitas rumah tangga, dan kebisingan yang disebabkan oleh transportasi di jalan utama kawasan penelitian. Berdasarkan fakta yang terjadi di lapangan dan analisis, Dinas Lingkungan Hidup Kabupaten Karanganyar memaparkan untuk kawasan penelitian dianggap masih aman, normal, dan dapat ditolerir sebagai kawasan perumahan yang tidak mengganggu aktifitas di dalamnya.

\subsection{ANALISIS DAN PEMBAHASAN FAKTOR PEMILIHAN LOKASI PERUMAHAN BAGIAN BARAT URBAN FRINGE KOTA SURAKARTA}

Analisis faktor yang mempengaruhi pemilihan lokasi perumahan dilakukan dengan Analytic Hierarchy Process (AHP). AHP merupakan metode untuk memecahan suatu situasi yang kompleks tidak terstruktur ke dalam beberapa komponen dalam susunan hierarki dengan memberi nilai tentang pentingnya setiap variabel. Analisis ini menggunakan penilaiain dari beberapa ahli sesuai dengan bidang keahliannya. Analisis AHP menggunakan software Expert Choice 11 untuk memasukkan data kuesioner dan kemudian mendapatkan hasil faktor yang paling berpengaruh dalam pemilihan lokasi perumahan bagian barat urban fringe Kota Surakarta. Gambar 5 merupakan rincian grafik tingkatan faktor yang mempengaruhi pemilihan lokasi perumahan bagian barat urban fringe Kota Surakarta.

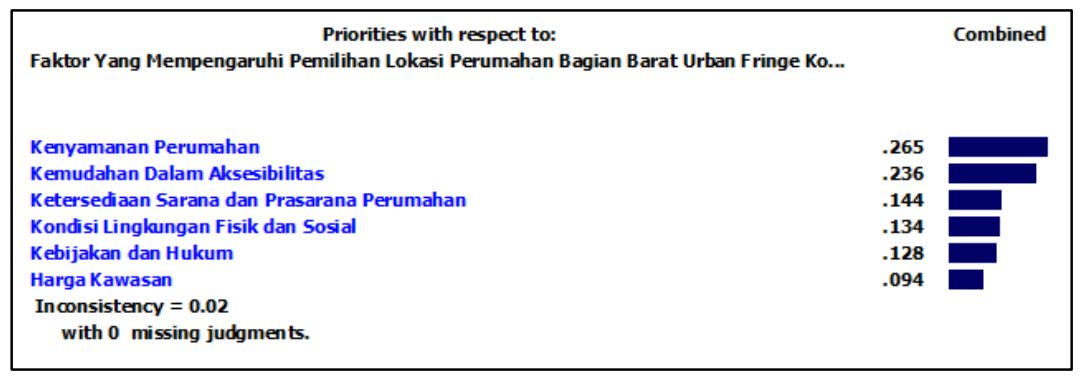

Gambar 5. Grafik Prioritas Matriks AHP Faktor Pemilihan Lokasi Perumahan Bagian Barat Urban Fringe Kota Surakarta

\subsubsection{Prioritas I: Kenymanan Lingkungan Perumahan}

Kenyamanan adalah rasa yang timbul karena situasi dan kondisi yang sesuai sehingga seseorang dapat merasakan kepuasan. Faktor kenyamanan yang dibahas adalah tingkat kebisingan dan tingkat polusi udara untuk kawasan perumahan. Faktor ini didukung pendapat dari Szelenyi dan Pichler Milanovich dalam Kahrik \& Tammaru (2008), Turner (1976), dan Budiharjo (1998) yang menyatakan bahwa kenyamanan merupakan faktor yang mempengaruhi dalam pemilihan lokasi perumahan di urban fringe.

Kenyamanan lingkungan perumahan menjadi faktor prioritas I (utama) yang paling mempengaruhi pemilihan lokasi perumahan bagian barat urban fringe Kota Surakarta. Dalam menentukan lokasi perumahan di urban fringe, stakeholder mempertimbangkan kenyamanan yang ditawarkan di lokasi tersebut dahulu. Hal ini didukung dengan kondisi lapangan dimana kenyamanan di lokasi penelitian memang cukup baik. Kenyamanan di lokasi penelitian dilihat dari kebisingan dan 
polusi udara. Kebisingan dengan data lapangan bahwa perumahan terbilang jauh dari kebisingan. DLH Kabupaten Karanganyar mendapatkan data tingkat kebisingan di kawasan penelitian sebesar $56 \mathrm{~dB}$ yang menunjukkan ke normalan sesuai dengan Keputusan Menteri Negara Lingkungan Hidup No. KEP-48/MENLH/11/1996. Sedangkan polusi udara dengan data lapangan bahwa substansi polusi udara di kawasan penelitian yaitu $\mathrm{SO} 2, \mathrm{NO} 2,03, \mathrm{H} 2 \mathrm{~S}, \mathrm{NH} 3, \mathrm{TSP} /$ debu, $\mathrm{Pb}, \mathrm{CO}$ yang berasal dari polusi udara kendaraan bermotor dan polusi udara hasil dari pembakaran sampah-sampah rumah tangga di kawasan penelitian. DLH Kabupaten Karanganyar mengatakan bahwa kawasan penelitian menurut aturan Kep. Gubernur Jateng No. 8 Tahun 2001 menunjukkan bahwa kawasan penelitian memiliki substansi kimia dengan batas normal. Berdasarkan data lapangan, DLH memaparkan untuk kawasan penelitian dianggap masih aman, normal, dan dapat ditolerir sebagai kawasan perumahan yang tidak mengganggu aktifitas di dalamnya.

\subsubsection{Prioritas II: Kemudahan Dalam Aksesibilitas}

Kemudahan dalam aksesibilitas adalah faktor yang mempengaruhi pemilihan lokasi perumahan urban fringe yang didukung oleh pendapat dari Pichler Milanovich dalam Kahrik \& Tammaru (2008), Wardana (2007), Luhst (1997), Koestoers (2011), Catanese \& Snyder (1989), Bourne (1975), dan Drabkin (1980). Pakar-pakar tersebut menyatakan bahwa lokasi yang mudah dijangkau oleh transportasi umum dapat memudahkan dalam pergerakan, baik dari segi manusia maupun barang.

Kemudahan dalam aksesibilitas sangat menguntungkan untuk para konsumen perumahan di kawasan penelitian. Dilihat pada indikator ketersediaan jaringan transportasi, jalan di kawasan memiliki kondisi yang baik, beraspal, dan beberapa jalan perumahan menggunakan paving block. Untuk indikator ketersediaan moda transportasi pada kawasan penelitian memiliki pelayanan moda transportasi umum yaitu adanya jalur trayek BST koridor 4 dan koridor 8 , sedangkan untuk trayek angkutan umum ada pada jalur 02, 08, dan 09 yang semuanya telah didukung dengan adanya halte/pangkalan moda transportasi umum.

Hasil data dan analisis yang telah dilakukan, kawasan penelitian yang berada di pinggiran kota Surakarta dengan segala aktifitas yang kompleks mengharuskan pergerakan menuju/ keluar pusat kota didukung dengan jaringan jalan yang baik, lengkapnya moda transportasi, dan halte sebagai pendukung aksesibilitas yang memudahkan pergerakan. Maka, kemudahan dalam aksesibilitas memang sesuai sebagai prioritas II faktor yang mempengaruhi pemilihan lokasi perumahan bagian barat urban fringe Kota Surakarta.

\subsubsection{Prioritas III: Ketersediaan Sarana dan Prasarana Penunjang Perumahan}

Ketersediaan sarana dan prasarana merupakan hal yang penting untuk penunjang kawasan perumahan. Ketersediaan sarana seperti sarana pendidikan, kesehatan, RTH, perekonomian, pemerintahan dan pelayanan umum. Ketersediaan prasarana seperti jaringan air bersih, jaringan listrik, jaringan persampahan, jaringan telekomunikasi, jaringan sanitasi, dan jaringan drainase. Faktor ini didukung oleh pendapat beberapa pakar seperti Catanese \& Snyder (1989), Drabkin (1980), dan Budiharjo (1998).

Hasil data dan analisis yang telah dilakukan, faktor ketersediaan sarana dan prasarana penunjang permukiman ternyata masih kurang prioritas dibandingkan dengan faktor kenyamanan (prioritas I) dan kemudahan dalam aksesibilitas (prioritas II). Hal ini dikarenakan prioritas I dan II sangat penting di dalam memilih lokasi perumahan di urban fringe. Masyarakat dari kota yang menganggap bahwa kota sudah penuh, sesak, dan padat dari berbagai aktifitas mengakibatkan keinginan berpindah ke kawasan urban fringe. Keinginan mendapatkan kehidupan yang nyaman dengan bertempat tinggal di daerah urban fringe memang tidak diragukan lagi. Dengan kondisi yang asri, ditemukan banyak lahan hijau yang membentang, minimnya polusi udara, dan kebisingan yang menjadikan kawasan pinggiran nyaman digunakan sebagai pembangunan perumahan. Ditambah lagi, ketika masyarakat ingin menuju/keluar pusat kota inti, sangat dimudahkan dengan adanya jaringan, moda, dan halte transportasi yang menjadikan kawasan pinggiran mudah dilalui dan dijangkau. Adanya jaringan jalan/koneksi menuju pusat, menyebabkan perpindahan manusia dan barang menjadi semakin mudah dan dengan berjalannya waktu ada pengembangan seperti pembangunan property-property baru di kawasan yang mudah dilalui. Maka, dengan ini ketersediaan sarana dan prasarana penunjang perumahan memang sesuai sebagai prioritas III faktor yang mempengaruhi pemilihan lokasi perumahan bagian barat urban fringe Kota Surakarta. 


\subsubsection{Prioritas IV: Kondisi Lingkungan Fisik dan Sosial}

Kondisi lingkungan fisik dan sosial menjadi salah satu faktor pada penelitian ini. Lingkungan fisik yang dibahas adalah topografi, jenis tanah, dan batas fisik sedangkan lingkungan sosial adalah keadaan sosial masyarakat yang ada di kawasan perumahan. Kedua hal tersebut merupakan penunjang suatu kawasan perumahan dan menjadi faktor yang mempengaruhi dalam pemilihan lokasi perumahan urban fringe dengan dukungan pendapat beberapa pakar yaitu Aca Sugandi (2005), Luhst (1997), Catanese \& Snyder (1989), Bourne (1975), Drabkin (1980), dan Budiharjo (1998).

Hasil data dan analisis yang telah dilakukan menunjukkan kondisi lingkungan fisik dan sosial menjadi faktor prioritas IV yang mempengaruhi pemilihan lokasi perumahan bagian barat urban fringe Kota Surakarta. Faktor ini dianggap kurang penting dibandingkan dengan faktor-faktor prioritas I, II, dan III. Prioritas faktor kondisi lingkungan fisik dan sosial ini kurang penting dari sebelumnya karena jika dilihat dari kemiringan tanah di kawasan penelitian adalah datar, mempunyai jenis tanah mudah untuk pembangunan, dan beberapa batas fisik yang secara garis besar dapat ditemukan di daerah perkotaan tanpa harus mencari lokasi di pinggiran kota. Kondisi sosial masyarakat juga mulai menyerupai kondisi masyarakat kekotaan. Masyarakat banyak bekerja di pusat Kota Surakarta (komuter) apalagi dengan aktifitas pekerjaan, tentu menghabiskan waktu penghuni perumahan bekerja di Kota Surakarta. Hal ini mengakibatkan aktifitas mereka jarang berada di perumahan dan menjadikan hubungan konektivitas penghuni perumahan dengan masyarakat di sekitarnya pun tidak terlalu kuat. Sehingga, dengan hasil paparan di atas, disimpulkan tidak begitu banyak pembeda antara perumahan di pinggiran dan di perkotaan dari segi kondisi lingkungan fisik dan sosial ini. Dengan alasan itu, faktor kondisi lingkungan fisik dan sosial dinilai rendah (prioritas ke IV) oleh stakeholder dalam memilih prioritas faktor yang mempengaruhi pemilihan lokasi perumahan bagian barat urban fringe Kota Surakarta.

\subsubsection{Prioritas V: Kebijakan dan Hukum Pendirian Perumahan}

Kebijakan dan hukum pendirian perumahan yang dibahas adalah kebijakan RTRW Kabupaten yang mengarahkan daerah tersebut sesuai dengan peruntukkan dan dokumen kepemilikan bangunan yaitu IMB per bangunan perumahan. Kedua hal tersebut merupakan penunjang suatu kawasan perumahan dan menjadi faktor yang mempengaruhi pemilihan lokasi perumahan urban fringe dengan dukungan pendapat dari pakar Catanese \& Snyder (1989) dan SNI 03-1733-2004.

Faktor ini terkalahkan dari faktor I, II, III, dan IV. Dari data lapangan dan hasil analisis, faktor kebijakan dan hukum menjadi faktor yang hampir tidak penting dalam pemilihan lokasi perumahan bagian barat urban fringe Kota Surakarta. Faktor ini dikatakan hampir tidak penting karena kebijakan dapat diubah seperti alih fungsi lahan pertanian menjadi permukiman yang sebelumnya telah di paparkan di atas. Hal ini terbukti pada 11 perumahan yang tidak sesuai pada zona permukiman. Developer memilih daerah urban fringe untuk kawasan perumahan karena lokasinya yang dianggap mempunyai banyak keuntungan dan masih banyak lahan (walaupun lahan hijau) yang bisa dibangun dengan pengalihfungsian lahan. Kesimpulan yang dapat ditarik adalah kebijakan bisa diubah sesuai dengan syarat dan ketentuan yang telah disepakati oleh pihak yang terlibat. Kebijakan pada permasalahan ini tidak mengikat sehingga dapat merubah suatu fungsi lahan pada zona peruntukkan. Ditambah lagi bahwa kebijakan RTRW Kabupaten yang selalu melakukan revisi sesuai dengan kondisi yang berkembang pada tahun sekarang hingga mendatang sangat memudahkan developer menggunakan lahan tersebut yang awalnya bukan untuk perumahan menjadi untuk perumahan. Berdasarkan teori beberapa pakar dan kondisi lapangan, dapat disimpulkan bahwa kebijakan dan hukum pendirian perumahan sesuai dengan segala penjelasan yang didapatkan untuk diberikan di tingkat prioritas ke $\mathrm{V}$ dalam pemilihan lokasi perumahan bagian barat urban fringe Kota Surakarta.

\subsubsection{Prioritas Vl: Harga Kawasan Perumahan}

Harga lahan/kawasan perumahan menjadi salah satu faktor dalam memilih lokasi untuk pembangunan perumahan baru di urban fringe dengan didukung pendapat pakar yaitu Catanese \& Snyder (1989) dan Hapsarinity (2013). Harga lahan/ kawasan dihitung dan dianalisis keuntungan yang didapatkan jika perumahan diletakkan di lokasi sesuai dengan harga lahan/kawasan yang telah ditetapkan.

Faktor ini merupakan yang tidak diprioritaskan dibandingkan dengan semua faktor yang telah dipaparkan sebelumnya dalam pemilihan lokasi perumahan bagian barat urban fringe Kota Surakarta. Faktor ini dikatakan tidak diprioritaskan karena 
menurut data di lapangan, perumahan yang berada di kawasan penelitian sebagian besar merupakan high-middle housing dengan keadaan konsumen yang high-middle income. Hal ini yang menjadikan harga lahan/kawasan bukan sebagai hal yang diprioritaskan untuk pembangunan perumahan di bagian barat urban fringe Kota Surakarta karena developer meyakini selalu ada konsumen dengan high-middle income yang memilih tempat tinggalnya di kawasan tersebut dan tidak terbebani dengan harga yang cukup mahal. Konsumen high-middle income biasanya mencari perumahan dengan kenyamanan yang baik dan aksesibilitas yang memudahkan konsumen menuju ke tempat penting. Sehingga dengan adanya hal ini, calon konsumen perumahan di kawasan penelitian lebih memprioritaskan faktor kenyamanan dan kemudahan dalam aksesibilitas. Berdasarkan teori pakar dan kondisi di lapangan, harga lahan/kawasan sesuai dengan segala alasan yang didapatkan untuk diberikan di tingkat prioritas ke VI atau faktor paling tidak penting dalam pemilihan lokasi perumahan bagian barat urban fringe Kota Surakarta.

\section{KESIMPULAN}

Perumahan di urban fringe menjadi salah satu akibat dari perkembangan wilayah perkotaan yang meluas hingga pinggiran. Kebutuhan perumahan merupakan permasalahan yang saling berkaitan dengan aktivitas kependudukan. Semakin banyaknya penduduk yang ada, maka semakin banyak pula kebutuhan perumahan. Fenomena bagian barat urban fringe Kota Surakarta mempunyai kriteria sebagai lokasi yang sesuai sebagai daerah perumahan dan permukiman. Faktor pemilihan lokasi perumahan dapat dilihat dari berbagai hal yang terdapat teori menurut beberapa pakar, sehingga ditemukan faktor-faktor yang berpengaruh dalam pemilihan lokasi perumahan bagian barat urban fringe Kota Surakarta.

Faktor prioritas I yang paling berpengaruh dalam pemilihan lokasi perumahan bagian barat urban fringe Kota Surakarta adalah kenyamanan lingkungan perumahan. Kenyamanan lingkungan perumahan meliputi tingkat kebisingan dan tingkat polusi udara di kawasan perumahan. Faktor prioritas II yang berpengaruh adalah kemudahan dalam aksesibilitas. Kemudahan dalam aksesibilitas ini meliputi ketersediaan jaringan transportasi, ketersediaan moda transportasi, dan ketersediaan halte di kawasan perumahan. Faktor prioritas III yang berpengaruh adalah ketersediaan sarana dan prasarana penunjang perumahan. Ketersediaan sarana seperti sarana pendidikan, kesehatan, RTH, perekonomian, pemerintahan dan pelayanan umum. Ketersediaan prasarana seperti jaringan air bersih, jaringan listrik, jaringan persampahan, jaringan telekomunikasi, jaringan sanitasi, dan jaringan drainase. Faktor pemilihan lokasi perumahan yang kurang berpengaruh adalah faktor prioritas IV yaitu kondisi lingkungan fisik dan sosial. Lingkungan fisik meliputi topografi, jenis tanah, dan batas fisik sedangkan lingkungan sosial meliputi keadaan sosial masyarakat yang ada di kawasan perumahan. Faktor prioritas $\mathrm{V}$ yang kurang berpengaruh adalah kebijakan dan hukum pendirian perumahan. Kebijakan dan hukum meliputi kebijakan RTRW Kabupaten yang mengarahkan daerah tersebut sesuai dengan peruntukkan dan dokumen kepemilikan bangunan yaitu IMB per bangunan perumahan. Faktor ini terkalahkan dari faktor I, II, III, dan IV. Dari data lapangan dan hasil analisis, faktor kebijakan dan hukum menjadi faktor yang hampir tidak penting dalam pemilihan lokasi perumahan bagian barat urban fringe Kota Surakarta. Faktor yang paling tidak mempengaruhi pemilihan lokasi perumahan bagian barat urban fringe Kota Surakarta adalah harga lahan/kawasan perumahan.

\section{UCAPAN TERIMA KASIH}

Penulis mengucapkan banyak terimakasih kepada segenap keluarga besar Prodi Perencanaan Wilayah dan Kota, Fakultas Teknik, Universitas Sebelas Maret yang telah mendukung dalam penyusunan jurnal ini.

\section{DAFTAR PUSTAKA}

Asteriani, F. (2010). Preferensi Penghuni Perumahan di Kota Pekanbaru. Ekonomi Pembangunan, 12(1), 77-91. DOI: 10.23917/jep.v12i1.207

Bayuprima, I., Sutarja, \& Yansen, I. (2016). Pengaruh Ketersediaan Faislitas Umum Terhadap Harga Jual Perumahan di Kawasan Mangapura. Jurnal Spektran, 4(2), 9-17. DOI: 10.24843/SPEKTRAN.2016.v04.i02.p02

Blaang, C. (1986). Perumahan dan Permukiman Sebagai Kebutuhan Pokok. Jakarta: Yayasan Obor Indonesia.

Bourne, L. (1975). Internal Structure Of The City. Oxford: Oxford University Press.

Budiharjo, E. (1998). Percikan Masalah Arsitektur Perumahan Perkotaan. Yogyakarta: Gajah Mada University Press. 
Catanese, A.J. \& Snyder, J.C. (1989). Perencanaan Kota. Jakarta: Erlangga.

Dinas Pekerjaan Umum (DPU). (1997). Rencana Kawasan Perumahan Perkotaan. Jakarta: KemenPUPR.

Drabkin, H. (1980). Land Policy and Urban Growth. Great Britain: Pergamen Press.

Giyarsih, S.R. (2009). Transformasi Wilayah. Disertasi Tidak Diterbitkan. Fakultas Geografi, Universitas Gadjah Mada, Yogyakarta.

Kahrik, A., \& Tammaru, T. (2008). Population Composition in New Suburban Settlements Of The Tallinn Metropolitan Area. Urban Studies, 45(5-6), 1055-1078. DOI: 10.1177/0042098008089853

Kalesaran, R., Mandagi, \& Waney, E. (2013). Analisa Faktor Faktor Yang Mempengaruhi Keputusan Konsumen Dalam Pemilihan Lokasi Perumahan Di Kota Manado. Jurnal Ilmiah Media Engineering, 3(3), 170-184. Diakses dari https://ejournal.unsrat.ac.id/index.php/jime/article/view/4278

Keputusan Menteri Negara Lingkungan Hidup No. KEP-48/MENLH/11/1996 tentang Baku Tingkat Kebisingan. Diakses dari https://baristandsamarinda.kemenperin.go.id/download/KepMenLH48(1996)-Baku_Tingkat_Kebisingan.pdf

Lollyanti, V., Normelani, E., \& Adyatma, S. (2017). Faktor Penyebab Pengembang Memilih Lokasi Perumahan di Kecamatan Sungai Tabuk Kabupaten Banjar. Jurnal Pendidikan Geografi, 4(1), 19-26. DOI: 10.20527/jpg.v4i1.3025

Luhst, K.M. (1997). Real Estate Valuation. USA: Principles Aplication Press.

Putra, B.Z., \& Rahayu, S. (2015). Faktor-Faktor Yang Mempengaruhi Pemilihan Perumahan dan Tipe Rumah di Perumahan Bukit Emerald. Jurnal Teknik PWK, 4(4), 681-691. Diakses dari https://ejournal3.undip.ac.id/index.php/pwk/article/view/10077

RPJMD Kabupaten Karanganyar Tahun 2018-2023. Diakses dari http://opendata.karanganyarkab.go.id/dataset/5cdc38f2-5b9c-44368f9c-f5bc0338b07a/resource/9fb77ae2-f749-4ec0-a2da-e125816c4884/download/bd044-rpjmd-karanganyar-2018-2023.pdf

RTRW Kabupaten Karanganyar Tahun 2013-2023. Diakses dari https://www.karanganyarkab.go.id/wp-content/uploads/2013/07/PERDANO-1-TH-2013.pdf

Saaty, T.L. (2008). Decision Makin with The Analytic Hierarchy Process. Pennsylvania, USA: University of Pittsburg.

SNI 03-1733-2004 tentang Tata Cara Perencanaan Lingkungan Perumahan di Perkotaan. Diakses dari http://sni.litbang.pu.go.id/index.php?r=/sni/new/sni/detail/id/694

Turner, J.F.C. (1976). Housing By People Towards Autonomy In Building Environments. London: Marion Boyars Publishers.

Undang-undang Nomor 1 Tahun 2011 tentang Perumahan dan Kawasan Permukiman. Diakses dari https://www.bphn.go.id/data/documents/11uu001.pdf

Wardana, W. (2007). Perilaku Pengembang Dalam Pemilihan Lokasi dan Pembebasan Lahan untuk Pembangunan Perumahan Sederhana. Yogyakarta: Andi Offset.

Yunus, H.S. (2000). Struktur Tata Ruang Kota. Yogyakarta: Pustaka Pelajar.

Yunus, H.S. (2008). Dinamika Wilayah Peri-Urban Determinan Masa Depan Kota. Yogyakarta: Pustaka Pelajar 